\title{
SALAOJIEN RUOSTETUKKEUTUMIEN TORJUMISESTA VESILUKKOJA KÄYTTÄMÄLLÄ
}

\author{
NIILO SEPPÄLÄ \\ Pellonraivaus Oy, Helsinki
}

Saapunut 16. 6. 1958 .

Etsittäessä keinoja salaojien ruostetukkeutumien torjumiseen on varsin vähän kiinnitetty huomiota mahdollisuuksiin estää tai vähentää niiden syntymistä vaikeuttamalla ilman vaihtumista salaojaputkistossa. Tätä menetelmää on ainakin eräissä vanhemmissä kulttuuritekniikan ammattikirjoissa ehdotettu käytettäväksi siten, että suositellaan eräiden muiden menetelmien lisäksi laskuaukon asettamista vedenpinnan alapuolelle (esim. 1, 2, 4, 8). Näyttää kuitenkin siltä, ettei tähän ajatukseen enää luoteta. Esim. KESo (5) ei menetelmää enää suosittele, vaan puoltaa sen sijaan vedenalaista salaojitusta, mutta tämäkin menetelmä on tavallisesti vaikeaa toteuttaa maiden viettävyyden vuoksi. Katsotaan; että rautarikkaiden vesien kulkiessa salaojaputkistossa tapahtuu raudan hapettumista ruostesakaksi niin pian kuin putki ei enää ole vettä täynnä ja siihen pääsee ilmaa. Näin ollen tutkijat ovat ryhtyneetkin hakemaan ratkaisua muista keinoista. Tällaisia tuoreimpia tutkimuksia ovat PuUstJärven ja JuUSElan (6) sekä Hallgrénin ja Östholmin (3), joissa on selostettu myös aikaisempia alan töitä.

\section{Suoritetut kokeet}

Tutkiakseni, voidaanko ruostetukkeutumia torjua estämällä ilman vapaa vaihtuminen salaojaputkistossa, aloitin keväällä 1955 kokeilut Salvelan kartanossa Piikkiössä, missä edellisenä syksynä olin havainnut putkistossa runsaasti savensekaisia ruostesakkautumia. Nämä eivät tosin vielä olleet aiheuttaneet salaojituksen joutumista epäkuntoon. Kokeilun kohteina ovat olleet ojastot 26 ja 28, jotka nähdään kuvassa 1. Salaojitus oli suoritettu vuonna 1929. Maalaji alueella on halkeilevaa aitosavea. Maalajin halkeilevuutta, mikä kokeen aikana usein jouduttiin toteamaan, voitaneen pitää epäedullisena tekijänä kokeen onnistumiselle. 


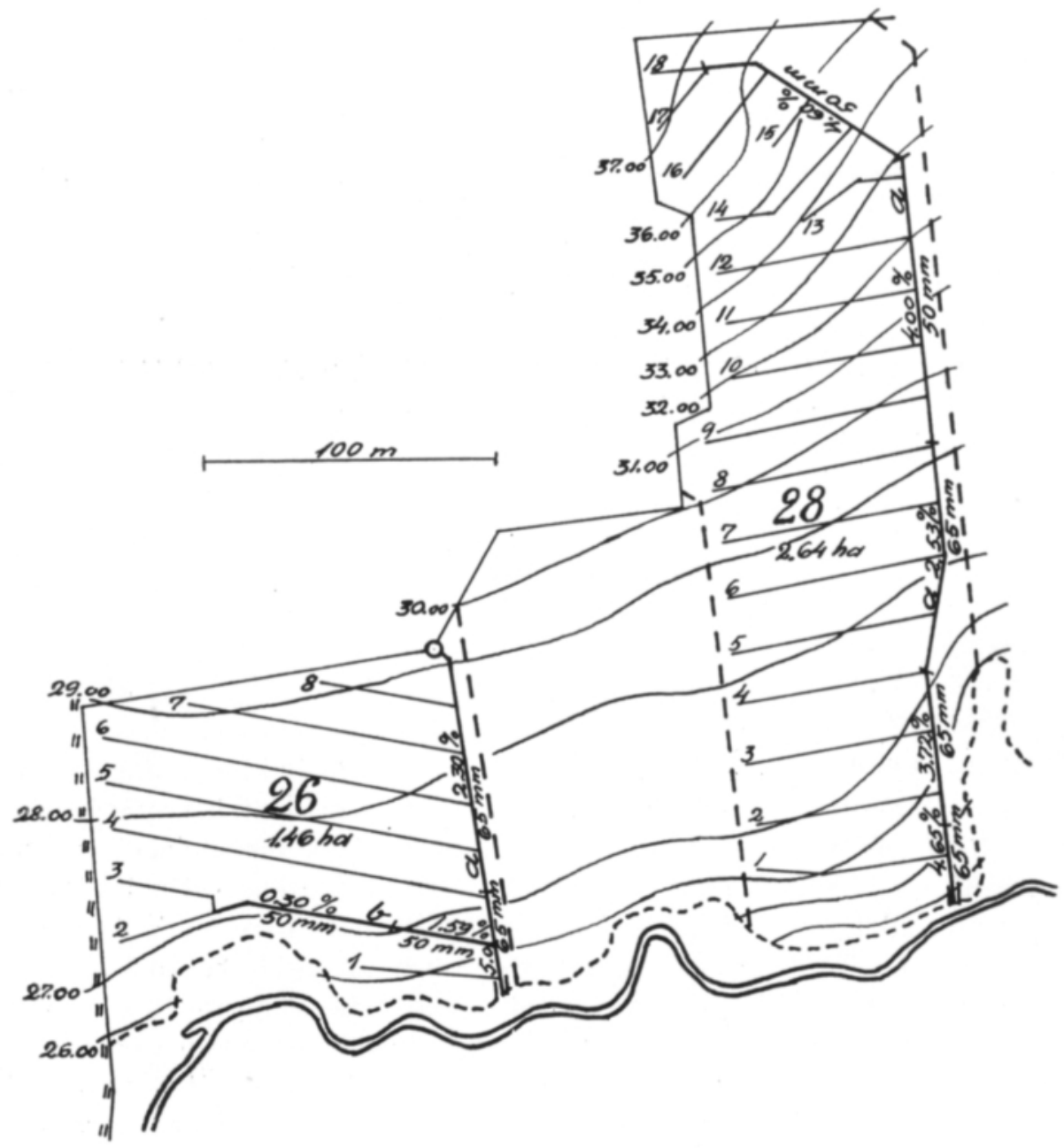

Kuva 1. Kokeiluojastot 26 ja 28 Salvelassa.

Ensimmäisenä päämääränä oli selvittää lisääntyykö laskuaukosta virtaavan veden rautapitoisuus sen jälkeen, kun ilman vapaa vaihtuminen estetään. Tässä tarkoituksessa otettiin kummastakin laskuaukosta 10 päivän väliajoin samanaikaiset vesinäytteet, yhteensä $5 \times 2 \mathrm{kpl}$ keväällä 1955 . Kesäkuussa ojaston 28 laskuaukko ilman vaihtumisen estämiseksi tehtiin vesilukoksi asettamalla se vinosti nousevaan asentoon. Vesilukon liettymistä peläten tehtiin sen yläpuolelle lisäksi rinnekaivo, jonka kansi ilman vaihtumisen vaikeuttamiseksi pantiin noin metrin syvyyteen maanpinnasta. Ojaston 26 laskuaukolle ja niskakaivolle ei vielä tehty mitään, ojasto jäi tällä kertaa vertailukohteeksi.

Tämän jälkeen jatkettiin vesinäytteiden ottoa. Kesän 1955 kuivuuden vuoksi ei laskuaukoista kuitenkaan ollut mahdollista saada yhtäaikaisia näytteitä ennen kuin marraskuusta alkaen. 30.5.56 oli kummastakin ojastosta saatu viisi näytettä. Näiden näytteiden, samoin kuin muiden tässä kirjoituksessa mainittujen vesinäyt- 
teiden rautapitoisuuden tutki valtion teknillisen tutkimuslaitoksen elintarviketeollisuuslaboratorio. Tulokset, jotka olivat rohkaisevia, esitetään edempänä olevassa taulukossa yhdessä myöhempien näytteiden tulosten kanssa.

Koeojaston 28 vedessä oli keväällä 1956 todettavissa lietettä kevyinä hiutaleina ( $\mathrm{d}=1-2 \mathrm{~mm})$. Tämä viittasi siihen, että ruostesakkautumat olivat alkaneet syöpyä, jolloin niihin tarttunut savi tai hiesu oli alkanut vapautua. Salaojavesien tavallinen savi- tai hiesulietehän ei ole hiutalemaista vaan aivan hienojakoista.

Kesällä 1956 ei vesinäytteitä loppukesän sateisuudesta huolimatta enää saatu, sillä koeojaston laskuaukosta ei tullut vettä. Laskuaukon nousevan asennon ja maan rakoilun vuoksi ojaston vesi purkautui maarakojen kautta laskuaukon sivuitse.

Lokakuun 10-11 päivinä 1956 tehtiin ojastoissa uusi koe. Tähänastinen vertailuojasto 26 suljettiin ilman vaihtumiselta vesilukolla laskuaukon yläpuolella ja niskakaivossa. Laskuaukon vesilukko tehtiin korvaamalla laskuaukon takana olevaa putkistoa 2.5 metrin pituudelta muovisella vesijohdolla $(\mathrm{d}=5 \mathrm{sm})$, joka kaarimaisesti taipui alaspäin keskiosaltaan n. 0.3 metriä. Täten saatiin vesilukko vettäpitäväksi. Tämänkin yläpuolelle tehtiin varovaisuussyistä rinnekaivo. Se on kuitenkin ainakin savimaassa tarpeeton, sillä edellä mainittua hiutalemaista lietettä ei vuorokausienkaan seisottamisella saa kerrostumaan, liete ainoastaan sakenee pohjalle päin ja lähtee heti leijumaan vedessä, kun tätä sekoitetaan. Tavallista salaojavesien savilietettä karkeampana se kyllä on herkempää laskeutumaan kaivoihin. Niinpä oli aikaisempi ojaston 28 laskuaukon taakse tehty kaivo täynnä lietettä ohuena vellinä, vaikka ainakaan savimailla ei rinnekaivoissa normaalisesti tapahdu mainittavaa lietteen kerääntymistä. - Niskakaivon vesilukko tehtiin samaan tapaan kuin ns. lietelukko nykyisin salaojakaivoissa tehdään, nimittäin siten, että kaivosta lähtevä salaoja nousee vedenpinnan alapuolelta noin kahden metrin matkalla varsinaiseen salaojan korkeuteen. Tässä lähtevä salaoja painettiin tavallista syvempään, eli n. 0.3 metriä vedenpinnan alapuolelle. Sitä paitsi tiivistettiin kaivo ja nouseva salaoja sementillä, piellä ja savella, ettei vesi valuisi niistä pois kuivana aikana. Myös ojaston 28 laskuaukkoa ja sen yläpuolella olevaa rinnekaivoa tiivistettiin samoilla aineilla ja rinnekaivo puhdistettiin savilietteestä.

Ojaston 26 imuojien ruostesakkautuneisuuden selvittämiseksi avattiin samalla kahden imuojan (5 ja 8) alaosat. Ensin putket vaakittiin päältä. Sen jälkeen ne otettiin ylös ja mitattiin sakkavahvuudet putkien yläpäissä. Oja 4:n alaosa oli siten tutkittu jo ennen tätä koetta, eli 8. 10. 54. Sakkavahvuudet nähdään kuvassa 2. Sakkojen punnitsemiseksi otettiin ojasta 5 kahdeksan putkea sakkoineen talteen.

Vesinäytteiden ottoa jatkettiin nyt kummastakin laskuaukosta. Useat yritykset menivät hukkaan sen vuoksi, että jommastakummasta laskuaukosta ei tullut vettä. Ojasto 28:n laskuaukko toimi tällä kertaa tiivistettynä jonkin verran paremmin, mutta ei ollut tullut vieläkään täysin tiiviiksi, siten että vedenpinta olisi aina ollut laskuaukon suulla tai lähellä sitä. Nyt saatiin sentään vesinäytteitä jo esim. elo- ja syyskuussa 1957 , kun edellisenä syksynä näytteitä ei saatu ennen ojasto 28 laskuaukon tiivistämistä. Ojasto 26 niskakaivon luona putkiston eristäminen ulkoilmasta ei myöskään liene ollut hyvä, sillä maa oli niin halkeileva, että niska- 


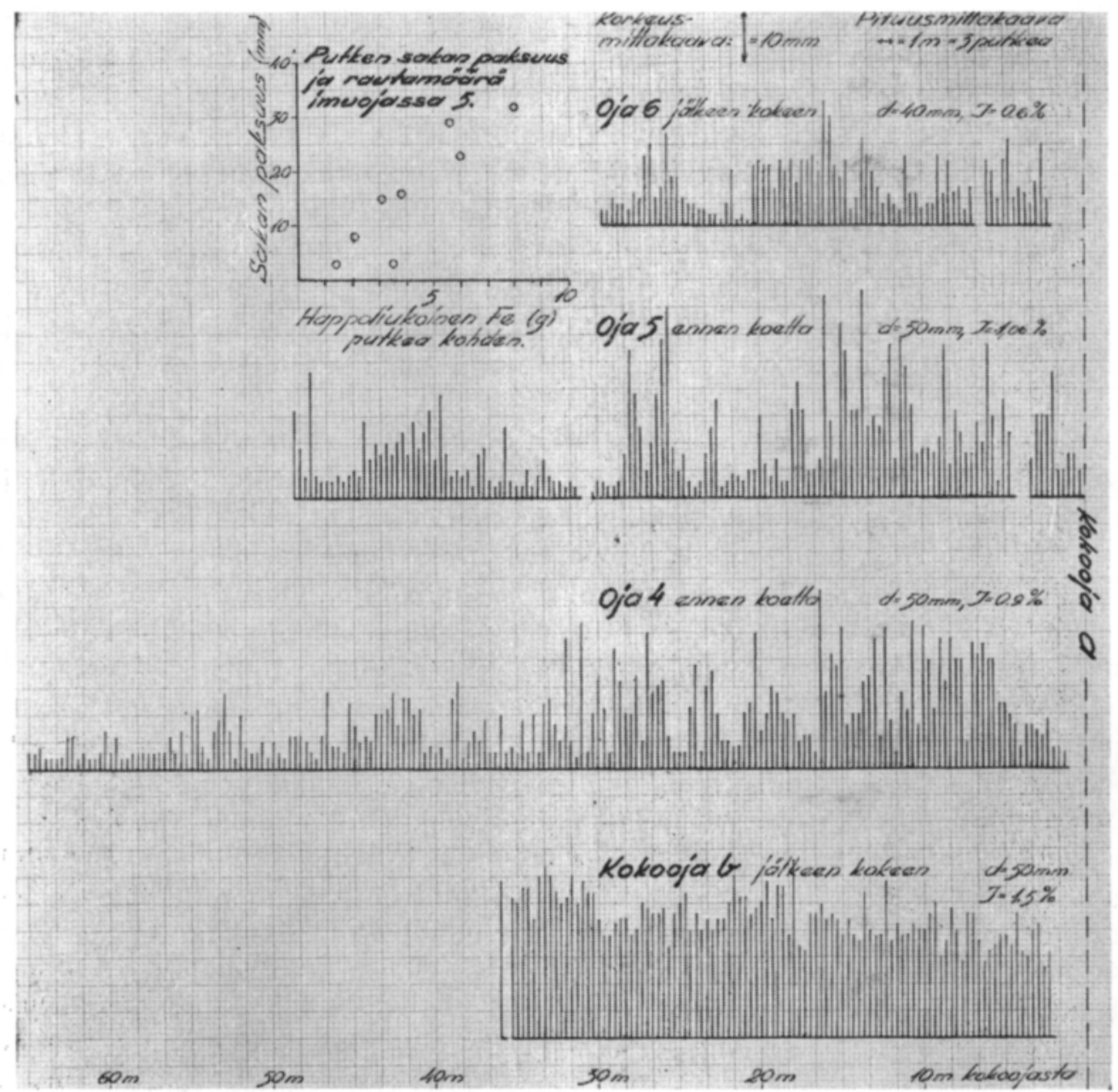

Kuva 2. Ruostesakkapaksuudet ojaston 28 salaojissa ja näyteputkien sakkojen rautamäărä.

kaivon altaista vähäisen vedentulon aikana vesi painui halkeamista maahan, nousematta altaiden kynnysten yli kaivoon.

Kummastakin laskuaukosta tuli etenkin keväällä edellämainittua hiutalemaista lietettä.

25. 9 . 57 oli kummastakin laskuaukosta otettu lisää 11 vesinäytettä, joiden rautapitoisuudet nähdään yhdessä aikaisempien näytteiden tulosten kanssa taulukosta ja graafisesti esitettyinä kuvasta 4 . 
Salvelan vesinäytteiden rautapitoisuus

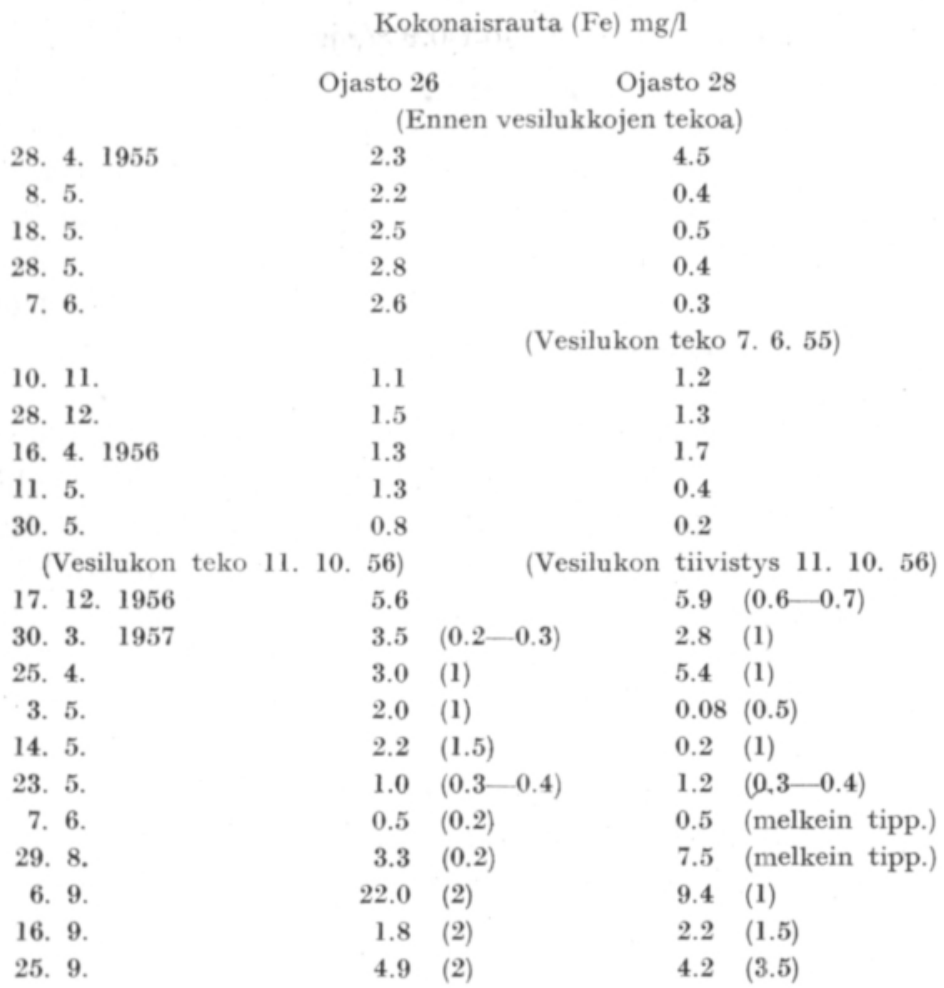

Taulukon viimeisissä näytteissä (17. 12. 56) alkaen on sulkuihin merkitty myös laskuaukosta virtaavan veden paljous vesikerroksen vahvuutena sm:issä laskuaukon suulla.

Jotta voitaisiin tutkia, oliko salaojien ruostesakkaisuus vähentynyt, avattiin 25. 9.57 ojastossa 26 imuojan 6 ja kokoojan b alaosat. Näiden, samoin kuin aikaisemmin avattujen imuojien 4 ja 5 sakkavahvuudet on esitetty kuvassa 2 . Imuoja 8 , joka myös oli avattu (syksyllä 1956), oli ollut ruosteesta vapaa.

Sakkaprofiileista on mm. todettavissa, että sakan paksuus tässä ojastossa kasvaa alempiin imuojiin päin sekä yksityisessä salaojassa alaspäin mentäessä. Nämä sakkavahvuuksissa nähtävät säännönmukaisuudet (yksityisessä imuojassa säännönmukaisuus näkyy sitä paremmin, mitä suurempi osa imuojasta on avattu) tukevat osaltaan sitä käsitystä, että ilman vaihtumisella laskuaukon kautta on tärkeä merkitys ruostetukkeutumien syntymiselle. Laskuaukon läheisyys sekä imuojien alajuoksuilla lisääntyvien vesimäärien (mikä aiheuttaa suurempia vedennopeuksia ja vedenkorkeusvaihteluja) aiheuttama parempi ilmanvaihto ovat selvästi lisänneet sakkavahvuuksia. Epäsäännöllisyydet taas johtunevat pääasiassa saumarakojen suuruusvaihteluista ja mahdollisesti myös saumarakojen tukkeutumisista, joiden syiden vuoksi eri saumoista putkeen tuleva vesimäärä vaihtelee.

Kaikki sakkautumat olivat putkisaumojen kohdalla, pääosaltaan niiden alapuolella, maksimikohdan ollessa esim. ojassa $4 \mathrm{n}$. 5 sm putkisaumasta, putkien 
muuten ollessa sakan peittämiä vain n. $1-3 \mathrm{~mm}$. (kts. kuva 3 ). Ruostesakan sivuprofiili näkyi loivenevan veden nopeuden kasvaessa, niinpä ojassa b se oli oleellisesti loivempi ja pitempi. Putous ojassa 4 on $0.9 \%$ ja ojassa b $1.5 \%$.

Että hyvä putous salaojassa ja siitä johtuva hyvä ilmanvaihto vaikuttaa tasoittavasti ruostesakkavahvuuteen näkyy myös Vihdin Karhulassa avaamastani salaojasta (7), jonka putous oli $2.2 \%$. Siinä sakan paksuus ei vähentynyt yläpäähän mennessä, ja yksityisessä putkessa sakan sivuprofiili oli loivempi ja pitempi.

Tilan säästämiseksi ei vaakituksen mukaisia ojien sivuprofiileja ole esitetty. Niiden vaikutusta sakkamääriin on vaikeata todeta, sillä esim. ojassa 4 ovat vahvimmat sakat yleensä töyrykohdissa, kun sitä vastoin ojassa 5 ne ovat paremminkin kuoppakohdissa.

Sakan paksuuteen ei kokeen voida katsoa vaikuttaneen yhdessä vuodessa. Ensin avatussa ojassa 6 ei huomio myöskään kiintynyt mihinkään muihin merkkeihin syöpymisestä, joskin mahdolliset vähäiset syöpymisjäljet saattoivat jäädä huomaamatta sen vuoksi, ettei niitä osattu tarkata, vaan huomio kiinnitettiin sakan paksuuden mittaamiseen.

Ojassa b sen sijaan oli valtaosassa putkia havaittavissa silmiinpistävät syöpymisjäljet sakoissa. Syöpymisjäljet olivat n. $0.5-1.5 \mathrm{sm}$ syviä, rosoisia vedenuurtamia uria sakan reunolla. Savi ja ruoste näyttivät olevan sakassa jossakin määrin kerroksittain ja ruosteen herkemmän syöpymisen vuoksi sakka varsinkin reunoistaan osoittautui liuskeiseksi. Niinpä joissakin putkissa oli sakan päällimmäisenä aivan irrallinen $2-3 \mathrm{~mm}$ vahva savi- tai hiesulastu. Lisäksi oli useiden putkien sakassa todettavissa madonreikien tapaisia syöpymiä hajallaan, jopa sakan alaosas-

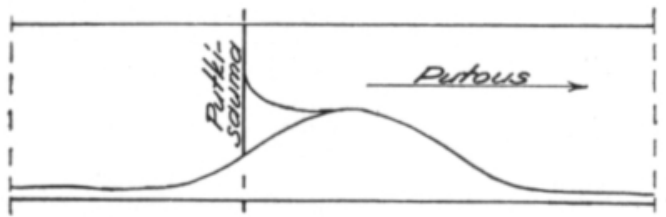

Kuva 3. Tyypillinen ruostesakkautuman pituusleikkaus ja poikkileikkaukset. a. ennen vesilukkojen tekoa, b. vuoden kuluttua vesilukkojen teosta.

sakin. Sakan yleinen väri oli selvästi harmaampi kuin ennen koetta avatuissa ojissa 4 ja 5. Piirros tyypillisestä sakkautumasta ennen ja jälkeen kokeen on kuvassa 3 . Näissä, kuten aikaisemminkin avatuissa ojissa putket puhdistettiin sakasta ja laskettiin takaisin ojaan, minkä jälkeen ne sorastettiin ja peitettiin.

\section{Muita havaintoja}

Kokeen lisäksi olen voinut myös tarkastaa toistakymmentä ruostetukkeutumista kärsivää tai kärsinyttä salaojitusta, joista useimmat ovat etelä-Suomessa. Kaikissa niissä pääsi ilma vaihtumaan laskuaukon kautta paitsi Euran Pelto-Kahmossa, missä se vaihtui maan pintaan saakka ulotetun rinnekaivon kautta. Rinne- 
kaivossa hapettunut kokoojan vesi oli Pelto-Kahmossa aiheuttanut ruostetukkeutumia kokoojan vedenalaisessa osassa.

Hollolan Riihelässä on n. 0.5 ha:n alue, jossa salaojitusta ei ole saatu toimimaan maan pohjavetisyyden ja veden rautapitoisuuden vuoksi. Ilma vaihtuu laskuaukon ja kahden tällä alueella olevan avoimen kaivon kautta.

Tavastin tilalla Kalajoella on ollut toistuvia ruostetukkeutumia ojastossa 9, joka on salaojitettu v.1930. Kokooja on jouduttu ruostetukkeutumien vuoksi puhdistamaan keskimäärin joka toinen tai kolmas vuosi. Puhdistettaessa kokooja on avattu n. 25 metrin välein ja välit on puhdistettu rassaamalla hevosvetoisesti, mikä viittaa varsin perusteelliseen puhdistukseen. Ojaston maalaji on hietaa. Kokoojan putous on $1.5 \%$. Ilma vaihtuu laskuaukosta kautta vuoden.

Tavastin ojasto 12 on salaojitettu v. 1932. Vaikka siinä veden rautapitoisuus on käytännöllisesti katsoen sama kuin ojastossa 9, on sitä jouduttu puhdistamaan keskimäärin vain joka kahdeksas vuosi. Tämä johtunee siitä, että tämän ojaston laskuaukosta ilma pääsee vaihtumaan vain vuoden kuivimpana aikana. Maalajina on hieta, jonka päällä on $0.3 \mathrm{~m}$ mutaa. Kokoojan putous vaihtelee $0.32-0.23 \%$.

Niissä Tavastin ojastoissa, joissa laskuaukko on aina veden alla, ei ruostetukkeutumia ollut esiintynyt.

Eräistä tarkastamistani ojastoista otin myös vesinäytteet rautapitoisuuden määräämistä varten. Tulokset olivat seuraavat:

Kokonaisrauta $\mathrm{Fe}$

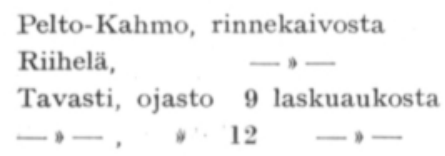

$\begin{array}{rrrr}26 . & 11.57 & 0.2 \mathrm{mg} / 1 \\ 27 . & 11.57 & 6.6 & \text { " } \\ 7 . & 8.58 & 12.9 \\ 7 . & 8.58 & 11.4\end{array}$

Rautapitoisuudeltaan harvinaisuus lienee Lappeessa Rasan tilalla ojasto 4:n imuojasta 7a 18. 7. 58 ottamani vesinäyte, jossa rautapitoisuus on $640 \mathrm{mg} / \mathrm{l}$. Näyte on paineellista pohjavettä sisältävästä hietahiesumaasta, joka on salaojitettu vv 1955-1956. Laskuaukko on vedenalainen, eikä ilma vaihdu minkään kaivonkaan kautta. Putkissa ei ollut ruostesakkaa, vaikka veden rautapitoisuus siis on esim. Tavastin veteen verrattuna n. 50-kertainen. Vettä kulki salaojassa puolillaan. Salaojaa avattaessa nähtiin sen veden pinnalla lipumassa sulaa voita muistuttavia keltaisia öljymäisiä läiskiä. Vesinäytettä otettaessa ja etenkin sitä pulloon kaadettaessa siitä saostui väriltään harvinainen musta sakka niin äkkiä, että vesi näytti kaadettaessa muuttuvan mustaksi.

\section{Johtopäätöksiä}

Edellä selostetut koetulokset ja havainnot vahvistavat käsitystä, että varustamalla salaojitusputkisto vesilukoilla voidaan ruostetukkeutumien syntymistä ainakin huomattavasti viivyttää ja luultavasti kokonaankin ehkäistä. Salvelan ojaston 26 kokoojassa b todetut ruostesakan syöpymisjäljet (kuva $3 \mathrm{~b}$ ) ja hiutalemaisen lietteen esiintyminen molempien ojastojen vedessä viittaavat myös siihen, 
että vesilukoilla voidaan aikaansaada putkiston puhdistumista sinne aikaisemmin sakkautuneesta ruosteesta. Menetelmä on huokea ja salaojitusta suoritettaessa usein toteutettavissa ilman lisäkustannuksia, sillä kokeessa laskuaukon vesilukon yläpuolella käytetyt rinnekaivot eivät ainakaan savi- ja turvemaissa ole tarpeen. Sitä voidaan helposti käyttää myös jo toteutetuissa salaojituksissa, joissa on todettu joko ruostesakkautumia tai ruosteista vettä. Helpoimmin on vesilukko tehtävissä, jos laskuaukko ja osa putkistoa on pantavissa viemärin alivesipinnan alapuolelle. Varma vesilukko saadaan myös edellä selostetulla tavalla taipuisasta muoviputkesta, jos putkikoko on sopiva. Ellei maa ole halkeilevaa ja jos laskuaukosta tulee vettä aina kesälläkin, voidaan se saattaa vedenalaiseksi vähätöisellä sopivasti vahvistetulla maapadolla laskuaukon edessä, jolloin saavutetaan se etu, että vesilukon ilmanpitävyyttä voidaan tarkkailla. Niskakaivon luona ojastossa 26 käytetty tapa tuskin on luotettava ja sama koskee myös ojaston 26 laskuaukkoa. Halkeilevassa maassa on varminta, ettei vesilukko ole aivan pellon reunassa, missä maan rakoilu on voimakkaampaa kuin muualla. Erittäin ruostepitoisia maita salaojitettaessa on putkituksen jälkeen syytä kiirehtiä salaojien täyttöä.

Niskavesien ym. muiden pintavesien ottamista ruostepitoiseen ojastoon on syytä välttää, sillä jo itsessään happipitoisina ne saostavat rautaa paitsi välittömästi myös välillisesti tuomalla happitäydennystä ojaston salaojissa olevaan ilmaan. Se, että kokeen jälkeen avattaessa ojia 6 ja b ojastossa 26 edellisessä ei havaittu ruostesakassa huomattavaa syöpymistä niin kuin jälkimmäisessä, voi johtua juuri tästä syystä, mahdollisesti myös maan halkeilevaisuudesta niskakaivon luona. Niskakaivon sadealue on n. 0.8 ha. Jos vuotuisesta sademäärästä $(600 \mathrm{~mm})$ arvioidaan niskakaivoon tulevan happirikkaana pintavetenä $30 \%$ happipitoisuuden ollessa $0.007 \mathrm{lt}$ happea liuenneena litraan vettä, saadaan niskakaivon kautta täten tulevaksi happimääräksi n. $10 \mathrm{~m}^{3}$, mikä määrä vastaa tämän ojaston putkistoon $(875 \mathrm{~m})$ mahtuvan puhtaan ilman $\left(2 \mathrm{~m}^{3}\right)$ happimäärää $\left(0.4 \mathrm{~m}^{3}\right) \mathrm{n} .25$ kertaa, joten niskavesillä (ja muilla pintavesillä) on oleellinen merkitys. Mainitut vedet tulisi sen vuoksi johtaa omaa salaojajohtoaan myöten joko omaan laskuaukkoonsa tai vasta ojaston laskuaukon ja sen yläpuolella olevan vesilukon välillä yhteiseen laskuaukkoon.

Jos salaojitettavan alueen jonkin osan todetaan tai arvellaan olevan muuta osaa huomattavasti rautapitoisemman, on sekin varminta erottaa omaksi ojastokseen.

Pohjavetisillä ruosteisilla mailla salaojien puutteellinen teho ei aina johdu ainoastaan ruosteesta, niin kuin helposti päätellään, kun sitä niissä tavataan. Syynä voi myös olla, että poisjohdettava vesimäärä, tarvittava salaojamäärä ja tarvittava täyttömaan sekä putkisaumojen vedenläpäisykyky on aliarvioitu.

Kokeen positiivista tulosta tukevat varsinkin em. havainnot sakan syöpymisestä ja savilietteestä. Vesinäytteiden analyysituloksien suuri hajonta ja näytteenottoaikojen eroavaisuudet sen sijaan vaikeuttavat johtopäätösten tekoa.

Keskiarvot analyysituloksista muodostuvat seuraaviksi (suluissa olevat luvut merkitsevät keskiarvoja, jotka on saatu jättämällä pois suuresti poikkeavat arvot 28. 4 . 1955 ojasto $28=4.5 \mathrm{mg} / 1$ ja 6.9 .1957 ojasto $26=22 \mathrm{mg} / \mathrm{l})$ :

Vesinäytteiden rautapitoisuuksien keskiarvot (kokonaisrauta) 


$\begin{array}{cccc}\text { Näytteitä } & \text { Ojasto } & \text { Ojasto } & \text { Raudan lisäys } \\ \text { kpl/ojasto } & 26 & 28 & \text { koetyön jälkeen } \\ & \mathrm{Fe} & \mathrm{Fe} & \mathrm{mg} / \mathrm{1} \\ & \mathrm{mg} / \mathrm{l} & \mathrm{mg} / \mathrm{l} & \text { ojasto } 26 \text { ojasto } 28\end{array}$

\begin{tabular}{|c|c|c|c|c|c|c|}
\hline Ennen koetöitä & 5 & 2.5 & 1.2 & & & \\
\hline Ojasto 28 suljettu & 5 & 1.2 & 1.0 & & 0.4 & $(0.8)$ \\
\hline Ojasto 26 ennen koetöitä yhteensä & 10 & 1.8 & & & & \\
\hline Molemmat suljettu (28 lisätiivistetty) & 11 & $4.5(2.8)$ & 3.6 & 2.7 & $(1.0)$ & 2.6 \\
\hline
\end{tabular}

Nämäkin tulokset tällaisinaan viittaavat siihen, että vesilukot ovat varsin voimakkaasti parantaneet raudan huuhtoutumista ojastoista siitäkin huolimatta, että maalaji on ollut hyvin halkeilevaa. Kun analyysitulokset esitetään graafisesti, niin että vaaka-akselilla on näytteen oton ajankohta (kuva 4) nähdään tosin, että

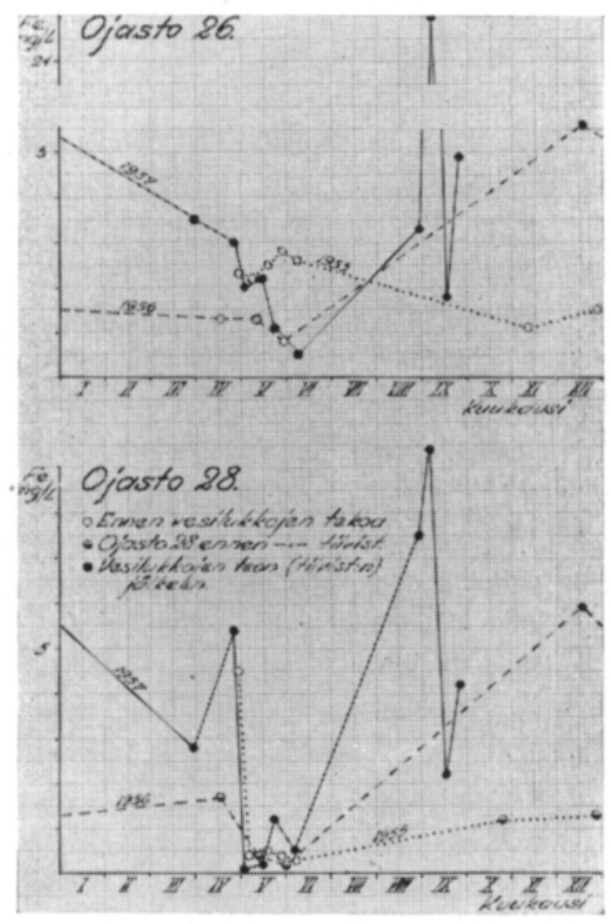

Kuva 4.

näytteet jakautuvat eri tavalla eri vuodenaikojen osalle ennen koetta ja sen jälkeen. Olisi siis ollut tarpeen ottaa enemmän näytteitä sekä ennen että jälkeen vesilukkojen teon.

Ojastosta 26 otettujen näyteputkien ja kuvassa' 2 esitettyjen sakkaprofiilien perusteella voidaan koko ojaston sakkamäärän arvioida sisältäneen happoliukoista 
rautaa $(\mathrm{Fe}) \mathrm{n} .10 \mathrm{~kg}$. Ojituksen iän $(26 \mathrm{v})$ ja vuotuisen laskuaukosta purkautuvaksi arvioidun vesimäärän (ojasto 1.3 ha $\times 600 \mathrm{~mm} \times 30 \%+$ niskavedet 0.8 ha $\times$ $600 \mathrm{~mm} \times 50 \%$, yhteensä n. $5.000 \mathrm{~m}^{3}$ vuodessa) nojalla voidaan arvioida, että sakan muodossa on rautaa pidättynyt putkistoon n. $0.08 \mathrm{mg}$ vesilitrasta. Verratessa tätä arvoa taulukossa esitettyihin ojaston 26 vesinäytteiden rautapitoisuuksiin, voidaan katsoa, että raudan hapettuessa vain murto-osa (ehkä $5 \%$ ) ruostesakasta on jäänyt putkistoon.

Jos edelleen arvioidaan ruostesakasta syöpyneen vuodessa n. $10 \%$, saadaan vastaavaksi raudan lisäykseksi n. $0.2 \mathrm{mg}$ Fe litrassa vettä. Yhteenlaskien edellä mainitun $0.08 \mathrm{mg} / 1$ kanssa päästään $0.3 \mathrm{mg} / \mathrm{l}$ :aan. Kun veden rautapitoisuus ojastossa 26 kuitenkin näyttää vesilukkojen teon jälkeen nousseen oleellisesti enemmän eli 2.7 (1.0) $\mathrm{mg} / \mathrm{l}$, vaikuttaa siltä, että myös putkiston ulkopuolella suojussorassa ja itse maassa oleva rauta on alkanut paremmin liueta.

\section{Yhteenveto}

Estämällä kunnollisilla vesilukoilla (hajulukoilla) ilman vapaa vaihtuminen salaojaputkistossa voidaan ruostetukkeutumien syntymistä putkistossa ainakin huomattavasti viivyttää ja luultavasti kokonaankin ehkäistä vieläpä, kuten esitetyssä kokeessa, aikaansaada putkiston puhdistumista sinne aikaisemmin sakkautuneesta ruosteesta. Jo menetelmän huokeudenkin vuoksi on tähän keinoon syytä kiinnittää vakavaa huomiota.

(1) Feilberg, Aa. \& Feilberg, C. L. 1937. Kulturteknisk vandbygning. $175 \mathrm{~s}$. Kobenhavn.

(2) Gerhardt, P. 1922. Kulturtechnik, 348 s. Berlin

(3) Hallgren, G. \& Östholm, C-O. 1957. Om utfällning av järn i dräneringsledningar. Grundförbättring $10,2: 87-101$.

4) Keso, L. 1942. Salaojitustyöt. 178 s. Porvoo, Helsinki.

$(5) \longrightarrow$ 1951. Salaojitustyöt. 299 s. Helsinki.

(6) PuUstjärvi, V. \& JuUsela, T. 1952. On rust precipitates present i drainage pipes and on the means of preventing their formation. Acta agr. scand. 2, 2: 131-152.

(7) SEPPÄLÄ, N. 1958. Salaojan pohjan epätasaisuuksien vaikutuksesta putkien liettymiseen. Maa- ja vesirakentaja 3: $154-159$.

(8) Vogler, Chr. A. 1903. Grundlehren der Kulturtechnik I: 2. 581 s. Berlin. 


\title{
UTILIZATION OF DRAIN TRAPS WITH A VIEW TO AVOIDING COVERED DRAINS BECOMING BLOCKED WITH RUST
}

\author{
NIILO SEPPÄLÄ
}

\section{Pellonraivaus Oy, Helsinki}

The paper presents the results of tests carried out during 1955-1957 at the Salvela estate, located in the Piikkiô commune, southwestern Finland, as well as observations made on the drainings of rust containing soils in other parts of the country.

The two draining systems used in the tests, are shown in Fig. 1. The soil in the area was heavy clay which was liable to crack. The tests primarily tried to ascertain whether the installing of drain traps would increase the iron content of the drain water discharging from the draining system. From each outlet 5 simultaneous water samples were taken. On June 7,1955 , the draining system 28 was closed by means of trap in the outlet. From each draining system 5 simultaneous water samples were again taken. On October 11, 1956, the draining system 26 was likewise closed by means of traps above the outlet and below the catch basin to prevent free air circulation. At the same time the trap of the draining system 28 was made water tight. Subsequently 11 simultaneous samples of water were still taken from each outlet. The iron content of the water samples is indicated in Table (p. 237) and Fig. 4.

The fixing and the tightness of the drain traps appear considerably to contribute to the increase the iron content of the water samples. In accordance with Fig. 4 the samples are, however, distributed in different ways in the different seasons of the year, prior to and after the fixing of the traps. A greater number of water samples would have been useful.

The effect of the test on the rust sediment of the covered drains was observed as follows: in draining system 26 and prior to fixing the traps the lower portions of laterals 4,5 and 8 were opened the density of sediment being measured in each tile. Since the traps had been effective in this draining system during one year, the lower sections of drains 6 and b were opened and examined. The sediment profiles are shown in Fig. 2, with the exception of drain 8, which appeared clear from rust sediment.

Regarding the density of the sediment the test cannot be proved as having been effective in one year. On the other hand, at least in ditch b, there were distinct corrosive traces present in the form of $0.5-1.5 \mathrm{~cm}$ deep channels at the edges of the sediment (Fig. $3 \mathrm{~b}$ ). Corrosion from the sediment is also indicated by the fact that after the traps were fixed in the water discharged from the outlets flaky ( $\mathrm{d}=$ $1-2 \mathrm{~mm}$ ) clay or fine sand silt were found, and it also settled in the silt basins made on the upper side of the traps. In general the drain water silt on clayey soils is quite finely divided and does not in any noteworthy degree settle in the silt basins.

Observations in respect to other drainings on rust containing soils show that in such drainings, if they are blocked with rust, the air in the drainage pipes has generally been able to circulate freely through the outlet. Merely the fact that during the greater part of the year the outlet is under the surface of water has essentially retarded its becoming blocked. A covered drain, the rust content of which touches such an unusually high level as $640 \mathrm{mg} \mathrm{Fe} / \mathrm{l}$, is still after a period of two years after draining quite clear of rust sediment, because its outlet is under the surface of the water.

As a conclusion it is maintained that the creation of rust stoppages in drainage pipes will at least in a noticeable degree be retarded and very possibly entirely obviated by means of drain traps even to the extent of bringing about a cleaning of the system of pipes from the rust sediment earlier deposited therein. The procedure is inexpensive and can frequently be put into effect without additional expenses. It can likewise be easily employed in existing draining systems.

The drain trap should be approximately $2-3$ metres long as well as watertight. In the event of the open ditch waters or other surface waters being conducted in a covered drain on soil containing rust, this should preferably be constructed apart from other draining systems and have an outlet of its own. 